\title{
Business and Society on the Transitional Periphery: Comparative Perspectives
}

Geoffrey T. Wood University of Essex, Essex Business School

Mehmet Demirbag University of Strathclyde, Strathclyde

Business School

\section{Abstract}

This article looks at business and society on the transitional periphery from a starting point rooted in the international business literature. Many transitional periphery countries have rich natural resource endowments or prosperous diasporas, making it relatively easy to attract inward FDI, chronic institutional weaknesses and policy failures notwithstanding. At the same time, such windfalls may dilute incentives for institution building or reform. We review trends emerging from the most recent scholarly work in the area, and highlight potential research agendas for the future.

\section{Introduction}

Much has been written about the nature of business and society, and the wider governance environment in central and Eastern Europe during the almost quarter century since the collapse of state socialism (c.f. Lane 2007). In contrast, very much less has been written on the "transitional periphery", the more remote post-Soviet economies of the Caucasus, Central Asia, and other peripheral outposts of former state socialist rule. What literature there is has tended to concentrate on macroeconomics and politics. However, these economies have become increasingly important not only owing to their strategic locale, but also in some notable instances, rich natural resource endowments that have attracted considerable FDI. Others have large diasporas, making for specific types of FDI, and policy responses. At the same time, they are often associated with corrupt and weak institutions, endemic conflicts (both border and internal), rising social inequality and the economic exclusion of a large proportion of their populations (Demirbag et al., 2010), leading to highly segmented developmental 
trajectories. The aim of this special issue is to provide new insights into the political economies of the transitional periphery from an international business perspective.

\section{Context}

What existing research points to, in many cases, is that following on from democratization, a shift to authoritarian and top-down leadership (Knox 2008; Murphy 2006) takes place. In many instances, nationalist agendas have been deployed as a substitute for democratic accountability (Bingol 2004; c.f. Demetriou 2002). In turn, politicians have been ambivalent, and sometimes contradictory, in driving economic reform agendas. To further complicate things, there appears to be little direct connection between the speed and nature of liberalization and economic growth, at least in the first decade of independence (Pomfret 2000; Spechler 2004). In some instances, the leadership has been dominated by soviet era politicians (Murphy 2006) and, in others, placed firmly under the sway of quasi-criminal oligarchs.

Given poor governance, emerging businesses battle with shifting rules and the challenges of placating rent seeking officials. Moreover, traditional supply chains extending into Russia have often been disrupted or broken down (Bevan et al. 2001) and, in other instances, continuing ties have made for dependence. Firms that do succeed often do so on the back of political patronage, making for challenges of sustainability in shifting political environments. At the same time, there is much diversity in the region, reflecting the relative role of diasporas, cultural dynamics, and specific historical legacies (Ardichvili and Gasparishvili 2001). Again, social protection is stronger in the Caucasus (Mitra 2009), providing some protection against the ultra-exploitation of labor. Finally, Kazakhstan is very much more integrated into global financial markets than many other countries in the region, making it particularly vulnerable to systemic shocks (ibid.) .

\section{The Transitional Periphery, Resources and FDI}

A number of these countries are resource rich which creates an imbalanced national production with overreliance on single source national revenue. As such, the 
experiences of oil and gas rich countries demonstrate that other segments of national economies may even be neglected. Further, overvalued currencies, regional imbalances, and institutional fluidity, and hence rising corruption, are common patterns amongst some resource rich transitional economies. (Ross 1999). Indeed, there is much evidence that this process is already well under way, even while oil resources are fast depleting (c.f. Van Wijnbergen and Budina 2011; Asadov 2005). In addition, all countries have faced rising social inequality, uneven and underdeveloped consumer markets, and potentially destabilizing levels of youth unemployment (Tarkhnishvili et al. 2005; Roberts and Pollack 2009). A further phenomenon has been the rise of quasi-states in the Caucasus (for example, Nagorno-

Karabakh, South Ossetia), disrupting trade and markets and making for open-ended tensions.

Despite this, natural resource endowments and, in some instances, historic links and/or prosperous diasporas have meant that countries on the transitional periphery have also become important destinations for foreign direct investment (FDI) and multinational firms' (MNCs) operations. FDI flows to the transitional periphery not only from Western developed economies, but also from other emerging countries and regions (South-South FDI) (UNCTAD, 2006). Given the transitional nature of institutions and complexities associated with governance of organizations, management of relations with governments, political elites, and trade unions appear to be increasingly challenging (Demirbag et al., 1998; Demirbag et al., 2010; Upchurch, 2012). Countries on the periphery of transition have administrative heritages which are significantly different than those of other emerging regions (Lubatkin et al., 1997) which present their own unique sets of challenges for developed and emerging market MNEs.

To date, transitional countries on the periphery are still a terra incognita and our stock of knowledge in business and management practices remain mired in anecdotal evidence. Given the importance of these resource rich countries and potential for investment, the neglect of publications focusing on periphery of transition is astonishing. Over the last two decades these countries have been undergoing profound and uneven institutional transformations which have ramifications for both emerging and developed country MNCs. Institutional settings in periphery of transition often necessitates MNCs to design different strategies to deal with the complex competitive 
dynamics in these countries (Batra, 1997; Demirbag et al., 1998; Kaynak et al., 2007).

\section{Conceptualizing Institutions on the Transitional Periphery}

But what types of institutional arrangements are encountered on the transitional periphery; and how are these likely to impact on firm behavior? The influential legal origin approach to institutions suggests that legal systems will be the ultimate determinant of firm behavior. It is held that all property rights depend on the law. A key distinction is between common law countries and civil law; in the former property rights are stronger, but in the latter they are mediated by the rights of other stakeholders (La Porta et al. 1999). La Porta et al. (1999) originally came up with a Soviet legal origin category, but later suggested that, over time, transitional countries would tend towards German legal origin, a type of civil law, reflecting long term legacies (c.f. La Porta et al. 2007). However, this approach tends to neglect the effects of variations in state enforcement capabilities, and the type of legislation enacted by parliaments; even in common law countries, key dimensions of corporate law are statutory, and not judge-made (Armour et al. 2009). This could reflect the wide disparity in economic performance of the transitional peripheral countries, supposed similar legal origin notwithstanding.

In contrast, the literature on comparative capitalism argues that national economic development and growth reflects a complex web of institutional realities and associated social relations (Hall and Soskice 2001; Whitley 1999). This literature initially concentrated on the developed world, with a key distinction being made between liberal market (or Anglo American) and coordinated market economies (the most developed continental European economies and Japan) (ibid.). It was held that, over time, other countries would evolve to one or other of these mature models (Hall and Soskice 2001). Later work sought to identify additional archetypes, inter alia, to explain the distinct and persistent features of the Mediterranean (or mixed market) economies and the emerging markets of Central and Eastern Europe (emerging market economies) (Hancke et al. 2007; Lane 2007). There have also been efforts to identify different types of capitalism encountered in developing economies in Africa, Latin America and elsewhere (see for example, Wood and Frynas 2006; Wood et al. 2010). 
Despite common pressures on liberalization, it is evident that many national economies are likely to retain distinct features, and this will account for persistent differences in types of corporate behavior. A real risk, however, is that more and more different types of capitalism are identified, until theoretical parsimony and analytical ease is lost. Again, many emerging markets have common features, including a strong segmentation between large firms and the state sector on the one hand, and the SME and informal sectors on the other. Such economies are also characterized by uneven institutional coverage on spatial lines, with much difference between the metropole and more geographically remote regions.

In practice, one can identify three different categories of state within the transitional periphery. Firstly, there are those countries associated with significant oil and gas reserves (e.g. Kazakhstan, Azerbaijan). Here, given weaknesses in regulation and political culture, the main concern has been with the regulation and management of the oil and gas sector, with a tendency to either neglect other areas of the economy or to cross-subsidize them in the interests of maximizing rents or dispensing patronage (c.f. Asadof 2005). Secondly, there are diaspora driven economies, such as Armenia and Nagorno-Karabakh. Here, it is possible for consumption and growth to take place that is at least semi-divorced from production (see Gevorkyan and Gevorkyan 2012). Investment decisions tend to be motivated by senses of history and historical responsibility, and personal ties, rather than financial criteria (Nielson and Riddle 2009). With this goes a tendency for politicians to neglect institution building or be concerned with sustainability, as they can be assured of an ongoing flow of funds from abroad. As the economy is geared to servicing the diaspora, who have insider contacts and insights, it means that other types of investor are proportionately disadvantaged. However, such investments may make a very substantial contribution to local capabilities and production networks (Plaza 2008), and more effective regulation and management can make for more sustainable growth (Gevorkyan and Gevorkyan 2012). Thirdly, there are those economies that do not enjoy oil and gas endowments and cannot count on being kept afloat from abroad; hence, FDI inflows into such economies have been relatively poor. Such economies, however, do not seem to have been much better at institution building than those in 
the other two categories (c.f. Boerzel and Pamuk 2012). Nor have politicians in such economies always proven very responsible, in some cases, experimenting with war as a solution to problems they experience and, in others, being primarily concerned with centralizing power and resources around their clans. Anti-corruption measures adopted in order to facilitate increased ties with European states has been used as a tool to secure and consolidate political power; hence, the influence of the EU appears not so much to have made things more democratic, sustainable or less corrupt, but rather to stabilize existing political trends and tendencies (Boerzel and Pamuk 2012).

\section{Emerging Issues}

In the following article, Kedia and Bilgili examine the importance of historical ties for equity share acquired in acquisitions by MNEs. They examine equity share ownership decisions of MNEs from an institutional perspective when MNEs acquire their targets in the transition post-Soviet economies of the Caucasus and Central Asia. Their findings highlight the importance of historical ties and regulative distance between home and host countries of acquisitions in the transitional periphery as historical ties increase the likelihood of higher ownership rate.

Mazhikeyev, Edwars and Rizow, however, look at the impact of institutional reforms (openness) and trade performance of Central Asian Republics. By adopting a gravity analysis approach, this paper highlights trade performance achieved by "more isolationist" states such as Tajikistan, Turkmenistan and Uzbekistan and countries with "more open" policies (Kyrgyzstan and Kazakhstan). It emerges that more isolationist countries over relied on natural resource related revenue streams to hike their international trade, while more "open policy" countries such as Kyrgyzstan and Kazakhstan achieved significantly higher trade performance.

Croucher focuses on labor relations in one of the key players of transitional periphery countries. His analysis focuses on Kazakhstan's oil and gas MNEs. Croucher's study supports the argument that a global system of industrial relations is emerging, which contributes to the convergence and divergence debate. 
Demirbag, McGuinness, Wood and Bayyurt focus on reinvestment decisions of MNEs operating in transitional periphery countries. This study highlights the relationship between different dimensions of corruption, institutional environment and reinvestment decisions by MNEs in the transitional periphery. The study further examines the differing influence of arbitrary and pervasive corruption on reinvestments of MNEs between transitional periphery and post-soviet transitional EU member economies. This paper contributes institutional theory by extending the variety of capitalism literature and formal institution's impact on reinvestment decisions. It emerges that the role of informal institutions becomes increasingly critical in reinvestment decisions of MNEs as government agencies arbitrarily and pervasively interact differently in differing legal and political systems.

Danilovich and Croucher focus on investment in personnel in Belarussian enterprises. What emerges from their study indicate that since the beginning of the global financial crisis there appears to be lesser investment in human resources which adversely affects capacity to attract FDI and modernize existing enterprises in Belarus. Danilovich and Croucher further argue that without modernization and FDI injection the existing business model of Belarussian enterprises may be unsustainable.

Serafini and Szamosi examine the level of implementation of HRM policies and practices in hotels of an MNE hotel chain both in the transitional periphery and advanced economies in a comparative manner. By examining an MNE's HRM practices in Caucasus and Central Asia through an in depth case study, Serafini and Szamosi identify a number of dissimilarities in terms of HRM practices. By adopting Whitley's employer/employee interdependence dimension, they identify differences in practices such as flexibility of employment, outsourcing and dismissal procedures. Despite such differences between socio-economic environments in respective countries, the luxury hospitality MNEs are able to implement uniform HRM policies and practices in transitional periphery and advanced economies.

Akbar and Kisilowski address the question of non-market strategies of businesses in the transitional periphery. They examine non-market strategies in accordance with countries' institutional development level. This exploratory study enhances our understanding of non-market 
strategies by comparing MNE subsidiaries with local firms both in Eastern Europe and Central Asia. Akbar and Kisilowski argue that low level economic and political institutionalization triggers local firms to use more proactive and high risk non-market strategies whereas in EEC countries which have relatively higher levels of institutional development both local firms and MNEs use more proactive non-market strategies.

Aslan, Larimo and Tarba examine Nordic MNEs' investments in the transitional periphery. They expand the market entry and establishment mode decision of MNEs by looking at institutional and firm level factors' influencing Nordic MNES' decisions when entering Eastern Europe, Russia and transitional periphery countries. Aslan et al., argue that in high risk transitional periphery countries Nordic MNEs tend to opt for green-field joint ventures whereas in low risk (high growth) countries these firms tend to prefer full acquisitions. This may be an important addition to variety of capitalism argument as institutional fluidity is higher in transitional periphery countries.

Gevorkyan examines conditions in the duo of Armenia and Georgia in the Caucasus region. His analyses focus on foreign direct investment (FDI), trade, human capital, and diaspora effects on social and economic transformation in these two countries of the transitional periphery. Gevorkyan argues that, despite their shared legacy, Armenia and Georgia are institutionally different economies. While Georgia adopts capitalist market structures faster than Armenia, Armenia appears to have more entrepreneurial and innovative capacity, yet both countries are struggling to recover from the adverse impact of the latest financial crisis to progress their structural transformations.

Majkhmadshoev, Ibeh and Crone examine institutional influences on SMES' export performance in two key transitional periphery countries of Tajikistan and Kyrgyzstan. From an institutionalist starting point, they explore the effects of variations in context on SMEs. While both Tajikistan and Kyrgyzstan share some common legacies from the Soviet era, there seem to be significant divergences in their current institutional environments which affect Tajikistan relatively more adversely than 
Kyrgyzstan. Despite a shared legacy, Kyrgyzstan has adopted a more open policy to accelerate market transformation which seems to create better performing SMEs compared to Tajikistan.

\section{Conclusion}

In exploring the role of international business in emerging markets, there has been a remarkable tendency to neglect the transitional periphery. Yet, flowing from a rich tradition of political and economic scholarship on the regions encompassed by this special issue, there is now a growing critical mass of work in this area. The editors were encouraged by the large number of high quality submissions attracted by the call for papers for this special issue. Unfortunately, it was not possible to include more than a sample of the best work on the subject. It is hoped that the papers in this collection will promote further international business scholarship in the region and, indeed, in other regions where similar forces are at play, including resource rich economies, diaspora orientated economies, and those that have experienced state socialist experiments.

\section{References}

Ardichvili, A. and Gasparishvili, A. 2001. "Socio-cultural Values, Internal Work Culture and Leadership Styles in Four Post-communist Countries: Russia, Georgia, Kazakhstan and the Kyrgyz Republic", International Journal of Crosscultural Management, 1, 2: 227.

Armour, J., Deakin, S., Sarkar, P., Siems, M. and Singh, A. 2009. "Shareholder protection and stock market development: an empirical test of the legal origins hypothesis", Journal of Empirical Legal Studies 6: 343-380.

Asadov, F. 2005. "The public oversight of oil projects in Azerbaijan, 2004-2007", International Social Science Journal, 57, 1: Supplement - 93-106. 
Batra, R. 1997. Marketing issues and challenges in transitional economies, Journal of International Marketing, $5(4): 95-114$.

Bevan, A., Estrin, S., Hare, P. and Stern, J. 2001. "Extending the economics of disorganization", Economics of Transition, 9, 1: 105-114.

Börzel, T. A., \& Pamuk, Y. 2012. "Pathologies of Europeanisation: Fighting Corruption in the Southern Caucasus", West European Politics, 35, 1: 79-97.

Bingol, Y. 2004. "Nationalism and democracy in postcommunist Central Asia", Asian Ethnicity, 5, 1: 43-60.

Demetriou, S. 2002. "Rising From the Ashes? The Difficult $(\mathrm{Re})$ Birth of the Georgian State", Development and Change, $33,5: 859-883$.

Demirbag, M., McGuiness, M., and Altay, H. 2010. "Perceptions of institutional environment and entry mode: FDI from an emerging country", Management International Review, 2010, $50(2)$ : 207-240.

Demirbag, M., Mirza, H., and Gunes, R. 1998. Political risk management: A case study of Turkish Companies in Central Asia and Russia", in Mirza, H. (Ed.) Global Competitive Strategies in the New World Economy, pp.283-309, London: Edward Elgar.

Gevorkyan, A. V. and Gevorkyan, A. V. 2012. "Factoring Turbulence Out: Diaspora Regulatory Mechanism and Migration Development Bank", International Migration, 50: 96-112.

Hall, P. and Soskice, D. 2001. An Introduction to the Varieties of Capitalism. In P. Hall and D. Soskice (eds.), Varieties of Capitalism: The Institutional Basis of Competitive Advantage, Oxford: Oxford University Press.

Hancke, B., Rhodes, M. and Thatcher, M. 2007. Introduction. In B. Hancke, M. Rhodes and M. Thatcher (eds.), Beyond varieties of capitalism: conflict, contradiction, and complementarities in the European economy. Oxford: Oxford University Press.

Kaynak, E., Demirbag, M., and Tatoglu, E. 2007. Determinants of ownership based entry mode choice of MNCs: 
Evidence from Mongolia, Management International Review, $2007,47(4): 505-530$.

Knox, C. 2008. "Kazakhstan: modernizing government in the context of political inertia", International Review of the Administrative Sciences, 74, 3: 477-496.

Lane, D. 2007. 'Post-State Socialism: A Diversity of Capitalisms?' in D. Lane and M. Myant (eds), Varieties of Capitalism in Post-Communist Countries, pp. 13-39. London: Palgrave.

La Porta, R. Lopez-de-Silanes, F. and Shleifer, A. 1999. Corporate Ownership around the World. The Journal of Finance, 54, 2, 471-517.

La Porta, R, Lopez-de-Silanes, F., \& Shleifer, A. 2007. The economic consequences of legal origins (No. w13608).

National Bureau of Economic Research.

Lubatkin, M.H., Ndaiye, M., and Vengroff, R. 1997. "The nature of managerial work in developing countries: A limited test of the universalist hypothesis", Journal of International Business Studies, $28(4): 711-733$.

Mitra, P. 2009. "The Impact of Global Financial Crisis and Policy Responses: The Caucasus, Central Asia and Mongolia", Global Journal of Emerging Market Economies, 2, 2: 189-230.

Murphy, J. 2006. "Illusory Transition? Elite Reconstitution in Kazakhstan, 1989 - 2002", Europe Asia Studies, 52, 3: 523-547.

Nielsen, T. M., \& Riddle, L. 2009. "Investing in peace: the motivational dynamics of diaspora investment in postconflict economies", Journal of Business Ethics, 89, 4: $435-448$.

Plaza, S. 2008. "Mobilizing the Diaspora: Creating an Enabling Environment for Trade, Investment, Knowledge Transfer and Enterprise Development, Africa's Finances: The Contribution of Remittances, 27, 56, : 27-56.

Pomfret, R. 2000. "The Uzbek Model of Economic Development, 1991-91", Economics of Transition, 8, 3, 733-748. 
Roberts, K. and Pollack, G. 2009. "New class divisions in the new market economies: evidence from the careers of young adults in post-Soviet Armenia, Azerbaijan and Georgia", Journal of Youth Studies, 12, 5: 579-596.

Ross, M. L. 1999. "The political economy of the resource curse". World Politics 51 (2) : 297-322.

Spechler, M. 2004. "Uzbekistan: the silk road to nowhere?", Contemporary Economic Policy, 18, 3, 295-303.

Tarkhnishvili, L., Voskanyan, A., Tholen, J. and Roberts, K. 2005. "Waiting for the Market: Young Adults in Telavi and Vanadzor", Journal of Youth Studies, 8, 3: 313-330.

UNCTAD. 2006. World Investment Report, 2006: FDI from Developing and Transition Economies: Implications for Development, United Nations, New York.

Upchurch, M. 2012. "Explaining persistence of dysfunctionality in post-communist transformation", in Wood, G., and Demirbag, M., Handbook of Institutional Approaches in International Business, London: Edward Elgar.

van Wijnbergen, S. and Budina, N. 2011. "Fiscal sustainability, volatility and oil wealth", Economics of Transition, 19, 4: 639-799.

Whitley, R. 1999. Divergent Capitalisms: The Social Structuring and Change of Business Systems. Oxford: Oxford University Press.

Wood, G., Dibben, P., Stride, C. and Webster, E. 2010. "'HRM in Mozambique: Homogenization, Path Dependence or Segmented Business System?", Journal of World Business, 46, $1: 31-41$.

Wood, G. and Frynas, G. 2006. The Institutional Basis of Economic Failure: Anatomy of the Segmented Business system, Socio-Economic Review, 4 (2): 239-277. 